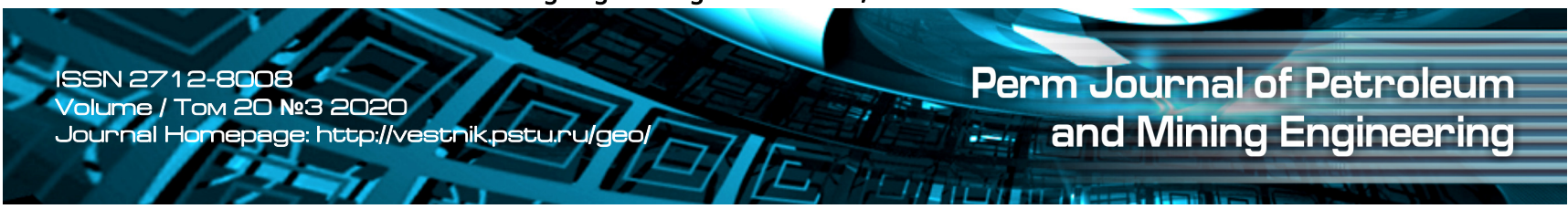

UDC 622.276

Article / Статья

() PNRPU / ПНИПУ, 2020

\title{
Laboratory Studies of Carboniferous Reservoirs of High-Viscosity Oil Fields Using Carbondioxide
}

\section{Stanislav A. Kalinin, Oleg A. Morozyuk}

PermNIPIneft branch of LUKOIL-Engineering LLC in Perm (3a Permskaya st., Perm, 614066, Russian Federation)

\section{Лабораторные исследования карбонатных коллекторов месторождений высоковязкой нефти с использованием диоксида углерода}

\section{С.А. Калинин, О.А. Морозюк}

Филиал ООО «ЛУКОЙЛ-Инжиниринг» «ермНИПИнефть» в г. Перми (Россия, 614015, г. Пермь, ул. Пермская, За)

\section{Received / Получена: 09.04.2020. Accepted / Принята: 25.08.2020. Published / Опубликована: 26.10.2020}

Keywords:

high-viscosity oil, oil recovery enhancement, carbondioxide, Permian-Carboniferous reservior of Usinskoye field, oil displacement, laboratory study, methodology, procedure, PVT, slimtube.
It is of current concern for the Permian-Carboniferous reservior of the Usinskoye field to develop low-permeable matrix blocks of carboniferous reservoirs, which contain major reserves of high-viscosity oil. To increase effectiveness of the currently used thermal oil recovery methods, the authors suggest using carbon dioxide as a reservoir stimulation agent. Due to a high mobility in its supercritical condition, $\mathrm{CO}_{2}$ is, theoretically, able to penetrate matrix blocks, dissolve in oil and, additionally, decrease its viscosity. Thus, $\mathrm{CO}_{2}$ applications together with a heat carrier could increase effectiveness of the high-viscosity oil recoveries and improve production parameters of the Permian-Carboniferous reservior of the Usinskoye field.

During carbon dioxide injections, including combinations with various agents, some additional oil production is possible due to certain factors. Determination of the influencing factors and detection of the most critical ones is possible in laboratory tests. So, laboratory studies entail the key stage in justification of the technology effectiveness. The paper deals with describing the laboratory facilities and methodologies based on reviews of the best world practice and previous laboratory researches. These aim at evaluating effectiveness of thermal, gas and combined oil recovery enhancement methods. In particular, the authors explore experimental facilities and propose methodology to perform integrated researches of the combined heat carrier and carbon dioxide injection technology to justify the effective super-viscous oil recovery method.

Актуальной проблемой разработки пермокарбоновой залежи Усинского месторождения является вовлечение в процесс разработки низкопроницаемых матричных блоков карбонатного коллектора, содержащих основные запасы высоковязкой нефти. С целью повышения эффективности применяемых в настоящее время тепловых методов увеличения нефтеотдачи авторами рассматривается вариант использования диоксида углерода в качестве агента воздействия на залежь. За счет высокой подвижности в сверхкритическом состоянии $\mathrm{CO}_{2}$ теоретически способен проникать в матричные блоки, растворяться в нефти и дополнительно снижать ее вязкость. Таким образом, применение $\mathrm{CO}_{2}$ совместно с теплоносителем потенциально может увеличить эффективность извлечения высоковязкой нефти и повысить показатели разработки пермокарбоновой залежи Усинского месторождения.

При реализации технологий закачки диоксида углерода, в том числе в комбинации с различными агентами, дополнительная добыча нефти возможна за счет проявления различных факторов. Определение влияющих факторов и выявление наиболее критичных из них возможно путем выполнения лабораторных экспериментов. Поэтому этап лабораторных исследований является ключевым при обосновании эффективности технологии.

Исследование посвящено описанию лабораторно-методического комплекса, разработанного на основе обзора мирового опыта и выполненных ранее лабораторных работ. Комплекс позволяет проводить необходимые исследования для оценки эффективности тепловых, газовых и комбинированных методов увеличения нефтеотдачи. В частности, авторами рассматривается экспериментальное оборудование и предлагается методология выполнения комплексных исследований технологии комбинированной закачки теплоносителя и диоксида углерода с целью обоснования эффективного метода извлечения сверхвязкой нефти.

Stanislav A. Kalinin (Author ID in Scopus: 57194691912) - Leading Engineer of the Department of Analytical Processing of Core Research Results (tel.: + 0073427170166 , e-mail: Stanislav.Kalinin@pnn.lukoil.com).

Oleg A. Morozyuk (Author ID in Scopus: 56006963800) - PhD in Engineering, Head of the Department of Research of Thermal Reservoir Stimulation Methods (tel.: + 0073427170166 , e-mail: Oleg.Morozyuk@pnn.lukoil.com). The contact person for correspondence.

Калинин Станислав Александрович - ведущий инженер отдела исследований тепловых методов воздействия на пласт (тел.: +007 3427170166 , e-mail: stanislav.kalinin@pnn.lukoil.com).

Морозюк Олег Александрович - начальник отдела исследований тепловых методов воздействия на пласт, кандидат технических наук (тел.: + 0073427170166 , e-mail: oleg.morozyuk@pnn.lukoil.com). Контактное лицо для переписки. 


\section{Introduction}

It is of current concern for the PermianCarboniferous reservior of the Usinskoye field to develop low-permeable matrix blocks of carboniferous reservoirs, which contain major reserves of high-viscosity oil (HVO). As shown in earlier researches [1], heat carrier filtrations and heating of the matrix part of the reservoir take place mainly along high-conductive channels, which are vast fracture networks for the heat carrier. Steam reaching distant reservoir areas through fractures contacts the low-permeable matrix and gives up heat via thermoconductive heating. Due to heavy reservoir fracturing, low permeability of the matrix and low mobility of saturating pores of the high-viscous oil, it is almost impossible to achieve high heating rates of the matrix part of the reservior with a heat carrier.

Carbon dioxide, due to high permeability (in the supercritical condition, $\mathrm{CO}_{2}$ has viscosity close to that of gases $[2,3]$ ), is, theoretically, able to penetrate the matrix blocks, dissolve in oil and assist in additional oil recoveries. Therefoore, the injection of $\mathrm{CO}_{2}$ together with a heat carrier can increase effectiveness of the high-viscous oil recoveries from the PermianCarboniferous reservior.

Based on literature reviews, the previous paper [4] by the authors hereof shows that the world practice has successful implementations of the carbon dioxide injection technology in complex carboniferous reservoirs saturated with high-viscous oil. At the same time, depending on particular geological and physical conditions, significant improvements of the technological parameters should be achieved.

However, due to high dicontinuity of reservoirs under study and high mobility of carbon dioxide, there exists a problem of the carbon dioxide breakthrough into production wells, which brings the need to use substantial (on a field scale) volumes of $\mathrm{CO}_{2}-1.84$ thou. $\mathrm{m}^{3}$ of $\mathrm{CO}_{2}$ per ton of oil produced. In case of the Permian-Carboniferous reservior, where Usinsk power park is viewed to be the only nearby source of carbon dioxide, obtaining substantial quantities of $\mathrm{CO}_{2}$ from flue gases does not seem possible. In this respect, the authors consider an option to use carbon dioxide as an addition to a heat carrier to increase efficiency of the currently used thermal reservoir stimulation methods (the cyclic steam well treatment and thermal steam treatment). This combined technology is very promising and active investigations are underway [5-8].

Laboratory studies is one of the key stages in the technology justification, since they allow us to evaluate the technological effect under closeto-reservoir conditions and obtain parameters necessary for further process scale ups. This article describes laboratory facilities and methodologies developed by the authors, which enable the research volume necessary for a comprehensive evaluation of effectiveness of the thermal, gas and combined oil recovery enhancement methods (EOR). In particular, the experimental equipment is considered, and methodology for performing integrated researches of the combined heat carrier and carbon dioxide injection technology to substantiate the effective super-viscous oil recovery method.

\section{Research Methodologies of Gas Agent Technologies (Using $\mathrm{CO}_{2}$ as an Example)}

If we implement gas and combined (together with heat carriers and various chemical agents) EOR under conditions of highviscosity oil reservoirs, additional oil production becomes possible due to some factors emerging when the reservoir oil contacts injected agents $[9,10]$. During dissolution of carbon dioxide in reservoir oil the following can be considered as main factors:

a) viscosity reduction. Dissolution of $\mathrm{CO}_{2}$ in oil leads to significant reductions of its viscosity (2-100 times and more), similar to applications of the heat stimulation methods. It should be noted that the higher the viscosity of the initial oil, the stronger the effect;

b) the oil volume increase (oil 'swelling'). This effect displays itself during dissolution of $\mathrm{CO}_{2}$ in oil and is important for oil recoveries due to two reasons: first, the volume of the displaced oil is directly proportional to its swelling degree; second, the oil phase in the reservoir becomes continuous (individual oil 
droplets join the continuous phase), which increases the oil single phase flow;

c) the dissolved gas manifestation. When the injection is over, $\mathrm{CO}_{2}$ starts releasing from oil, thus, driving oil to the well bottom. In case of the high-viscous oil recovery (HVO) during the carbon dioxide release, a stable gas-oil foam may be generated in the reservoir, able to limit continuous oil phase formations in the reservoir and its breakthrough to the production wells. This may promote an increase in the reservior encompassment with the displacement process.

Except for the above, during $\mathrm{CO}_{2}$ dissolving in the high-viscous oil, such factors may manifest to various extents, as extraction of light, medium oil components and their transition to the light (carbonic acid) phase, and reduction of the surface tension at 'reservoir oil $-\mathrm{CO}_{2}$ '. In addition, an acid is formed when carbon dioxide contacts the reservoir water, thus, dissolving the carboniferous rock and increasing permeability and volume of pores.

In general, the completeness of oil recoveries and effectiveness of carbon dioxide injections, except for reservoir conditions (temperature, pressure, permeability, presence of fractures, etc.) and reservoir oil parameters (composition, viscosity, presence of asphalt, resin and paraffin (ARP) reserviors, etc.), is also influenced by technological parameters of $\mathrm{CO}_{2}$ injection process (for example injection rate and pressure, etc.). In addition, negative factors should be considered, which may include, for example, corrosion of oil field equipment, asphaltens settling to free phases and reservioring on pore walls, premature breakthroughs of carbon dioxide being injected, etc. Problems specific for the carbon dioxide injection technologies are described, for example, in [11-13].

As there exists practically no expertise in experimental studies of HVO recovery carbon dioxide injection-based technologies in Russia, an extensive survey and analysis of the world practice was performed. As result of a compilation of literature sources and own experience, with regard to opportunities offered by modern equipment, an integrated research methodology was developed, including the following stages: preparation of core reservoir models and reservoir fluids models, standard and special set of PVT studies of reservoir fluids and their mixtures with gas a agent, oil displacement evaluation, filtration tests on core models made of standard and full-scale samples (or sand-packed tube reservoir models), process scaling and further technology improvement within a pilot area using special software.

Preparation of reservoir models and reservoir fluid models includes the following stages:

a) core sampling, determination of their reservoir properties and structural and textural peculiarities;

b) arrangement of reservoir models with parameters characterizing zones of the study object;

c) building core reservoir models with parameters characteristic for the studied object, or with parameters necessary for the study objectives;

d) preparation and determination of reservoir fluid parameters;

e) preparation of the recombined reservoir oil model, the gas and reservoir water model with properties close to physical and chemical properties of reservoir fluids.

It is necessary to note that depending on research objectives, for example, for parametric experiments where it is necessary to exclude the porous medium influence (rock composition variability, pore structure, etc.) on the results obtained, instead of core models samples are cut from uniform sandstone (Berea, etc.) or artificial porous media are made of quartz sand or glass microspheres may be used. This does not eliminate the need to use actual core samples, which make it possible to model close-to-reservoir conditions (which is of special importance, for example, during determination of oil displacement factors).

Preparation of a reservoir oil model should be approached thoroughly, as its composition determines characteristics of physical and chemical processes during its contact with a gas agent. For laboratory researches, the recombined reservoir oil model should be used, made with a model gas or gas taken from a production separator. 
Thorough preparations of porous media samples and reservoir fluid samples improve reliabiity of results of further laboratory experiments and numerical simulations.

PVT studies of the oil model and its mixtures with the gas agent in various proportions are an important part of the laboratory stage behavior of the oil and carbon dioxide mixture formed under reservoir conditions. Many researchers consider them as the determining factor in evaluation of $\mathrm{CO}_{2}$ injection technology effectiveness $[7,8]$.

The complex includes:

a) standard PVT studies of the recombined oil model [13] (determination of density and viscosity, saturation pressure and volumetric factor at different thermobaric conditions);

б) special PVT studies of mixtures of the recombined oil model and gas agent in various proportions [14-18] (determination of a dependency of the mixture properties on thermobaric conditions and a gas concentration, a study of a gas agent dissolvability in oil, determination of a degree of the oil volume change (swelling test) [17-19], determination of resins and asphaltens destabilization conditions [20], etc.).

Studying the nature of interactions between the reservoir oil and gas agent includes determination of minimum miscibility pressure (MMP) and of oil displacement condition by a gas agent using various methods. So-called slim tubetest [21-23] is the most widely used method of the laboratory determination of MMP, as it helps to determine the oil displacement condition with a gas [24], and also perform proportioning of a dissolving agent composition.

Also, the rising bubble method (RBM) [25] and vanishing interfacial tension (VIT) [26] are widely used now.

The research results at this stage make it possible to understand physical and chemical processes during a dynamic contact of the injected gas with the reservoir oil. Apart from that, the obtained data are used later in development and adjustment of fluidal and compositional models.
Filtration experiments include:

a) special (parametric) filtration experiments using core or sand-packed tube reservoir models (artificial media) to study peculiarities of the displacement process at variations of parameters (influence of pressure and temperature, permeability and fracturing, determination of optimal stimulation parameters (for example, agent plug size or ratio of displacement agents injection volumes)) depending on a simulated injection scheme [27-30];

b) core studies with the purpose to study the displacement ability of $\mathrm{CO}_{2}$ at different injection schemes $\left(\mathrm{CO}_{2}\right.$ displacement [31, 32], cyclic action by $\mathrm{CO}_{2}$ [33, 34], alternating injection of $\mathrm{CO}_{2}$ and water [35], combined stimulation with heat carriers [36, 37], including different additives (hydrocarbon solvents [37], surfactants [38, 39], etc.)).

It is possible to single out microsimulation using artificial porous media finding regularities and peculiarities of the oil displacement process at a level of separate pores and pore channel systems by visual observation [35].

Filtration experiments let us perform a preliminary evaluation of the technology effectiveness under different thermobaric conditions, study peculiarities of displacement at occurrence of various factors, evaluate effectiveness of different $\mathrm{CO}_{2}$, injection schemes, and also obtain information necessary for a further process scaling.

Technology scaling and optimization are performed by numerical simulations using dedicated simulators (for example, simulator by Computer modeling group - CMG), including thermal and compositional modules. Meanwhile for development and adaptation of the pilot area (sector) results, laboratory studies are used [40, 41]. During express screening, various development scenarios are simulated, which differ in the agent injection schemes, sizes of injected agents plugs, well arrangement schemes, etc. As result of calculations, optimal technology implementations are obtained, which are further used to perform feasibility studies. 


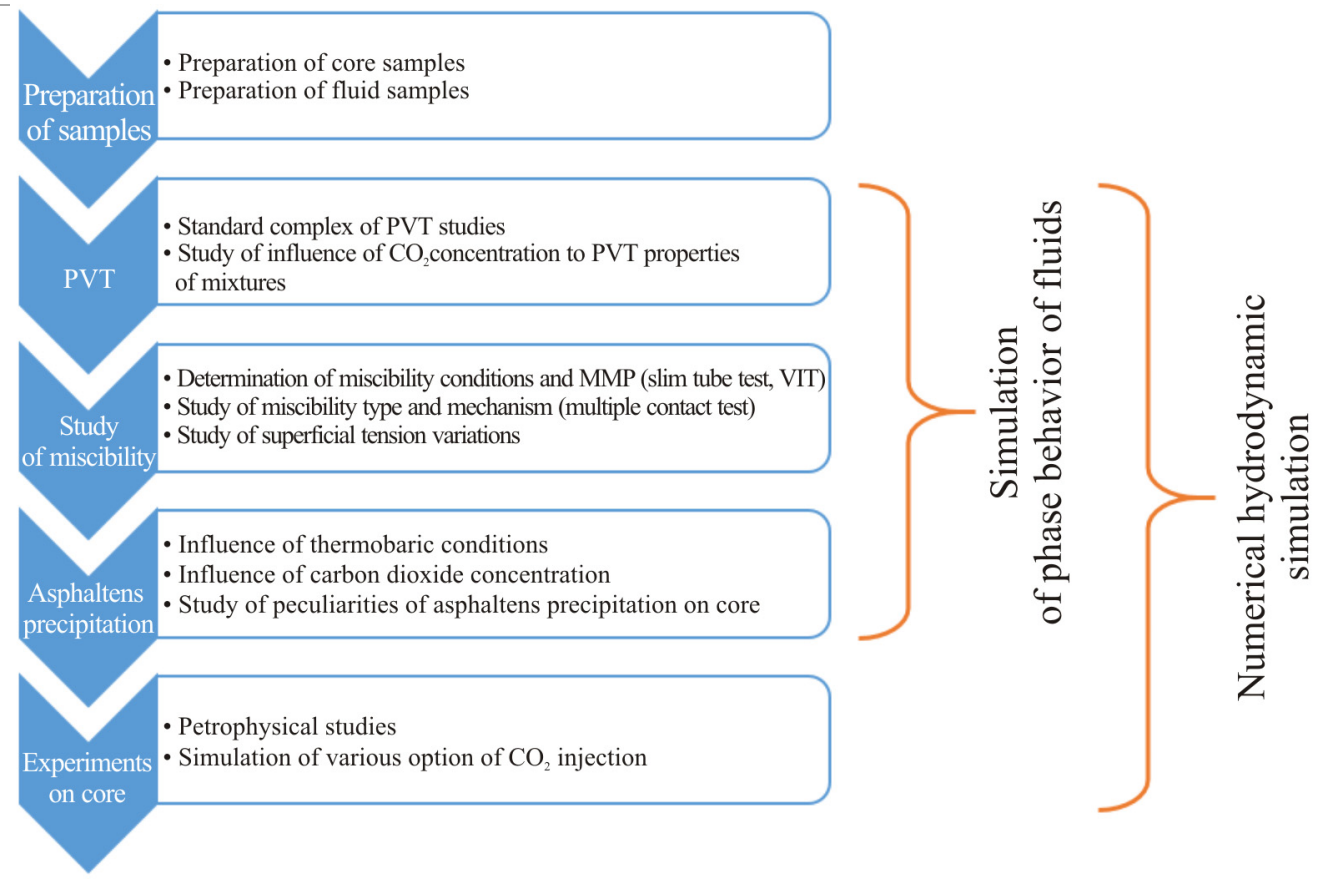

Fig. 1. Methodology of integrated studies of oil recovery enhancement methods based on carbon dioxide injection

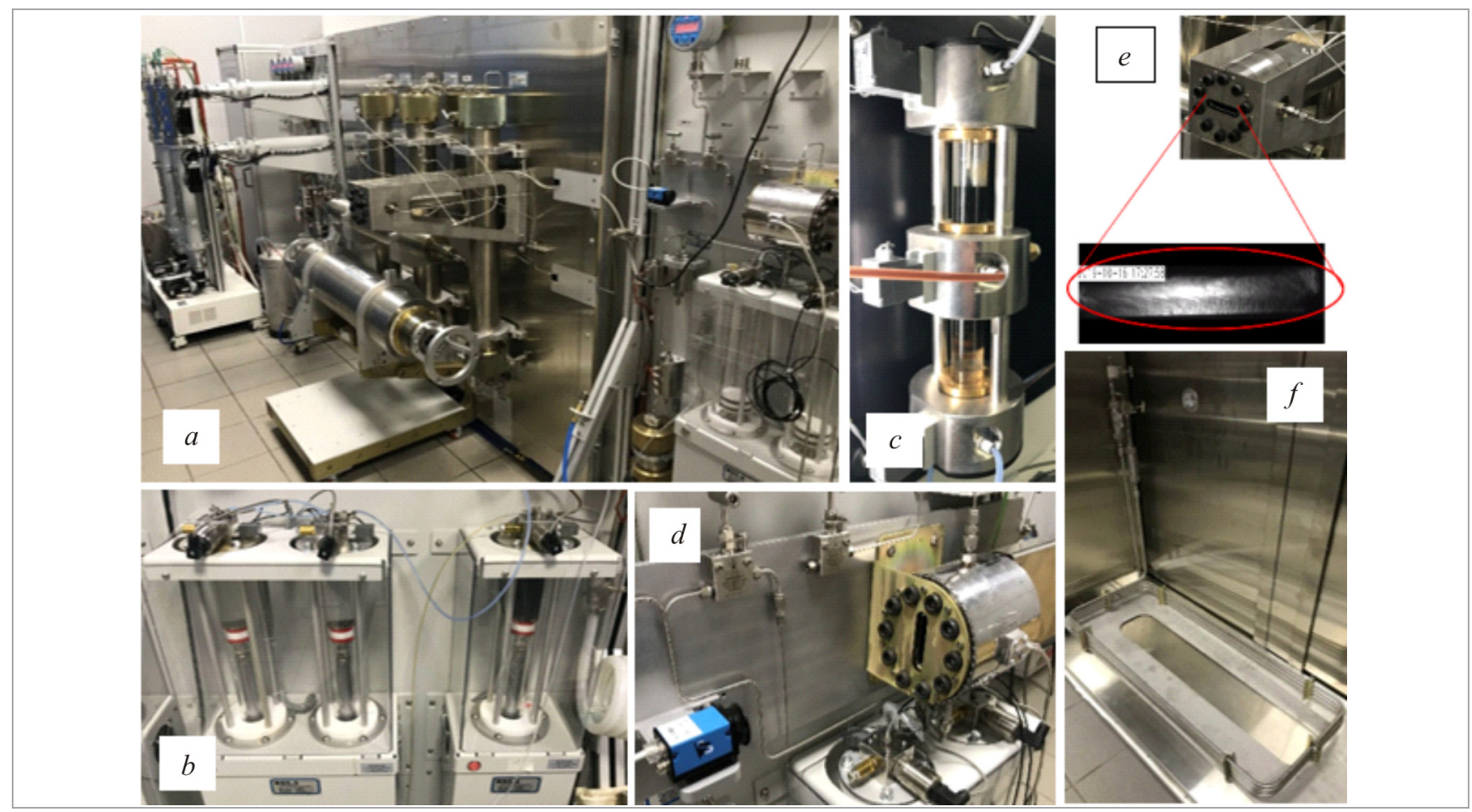

Fig. 2. Laboratory facilities to study heat and gas EOR: a) general view of the installation, b) piston flow meters, c) a visual three-phase separator, d) a block for measuring the superficial tension at reservoir conditions, e) a visual cell, $f$ ) a slim model in a thermal cabinet

This stage implementation improves the research quality due to an increase of the technology evaluation scale and increase of informativeness of the results obtained, and also gives an opportunity to optimize the laboratory study scheme with regard to understanding the data volume necessary to create models. 
The described research methodology is schematically presented in Fig. 1 showing separate research stages and their interrelations.

\section{Description of the Laboratory Equipment}

For the research, special laboratory facilities were created to perform filtration experiments on core and sand-packed reservoir models using various displacing agents (water, gas, steam, chemical compositions) in a wide range of temperatures and pressures (Fig. 2, a). The facilities are designed to perform experiments on two- and three-phase filtrations, and also a simultaneous performance of two independent experiments (fluids injection and withdrawal, pressure differential measurement, measuring quantity of oil, water and gas being withdrawn, dynamic analysis of a componential composition of fluids being withdrawn).

The filtration installation includes a number of functional blocks (systems): a formationpressure block, a fluid supply block, a gas agent preparation and supply block, two core holder blocks, two slimtube model blocks, two pressure measurement blocks, two back pressure blocks, two fluid volume measurement blocks, steam generation block, hydraulic line cooling block, superficial tension measurement block, data collection block and chromatographic complex for EOR control and monitoring.

Fluids supply, core holders, pressure differential measurements, back pressure and data collection blocks are of a classic design. Other blocks should be described separately:

- the formation pressure block creates and maintains the independent overburden pressure in two core holders. The block consists of a piston pump, automatic valves providing for automatic pump operations on both core holders, and pressure sensors;

- the gas agent preparation and supply block includes a booster pump to transfer gases from cylinders, a high pressure vessel for gas mixture accumulations, a double plunger pump and system of manometers and safety valves. The block pressurises and heats gases to necessary thermobaric conditions, and supply to core holder blocksor slimtube;

- the slimtube block includes slimtube models themselves, a special piston vessel for a gas agent, a filter at the exit end of the model and a high pressure visual cell. The visual cell is design to perform photo- and videorecording of phase behaviors at different stages of an experiment on oil displacement by gas agents;

- the fluids volume measurement block at the exit of the reservoir models includes a threephase visual separator, special piston flowmeters installed after the separator, and pressure sensor system. The separator, using digital cameras, controls levels of the phase separation 'water - oil' and 'oil - gas'. During the movement of the phase separation levels, the piston flowmeters pump out corresponding phases, while the constant pressure is maintained in the system. During the experimentation, the block design directs the fluid stochromatographic complex with a given periodicity, and piston flowmeters could be correspondingly set to do it. Application of the piston flowmeters is determined by a possibility to perform measurements of wide range volumetric phase flows (Table);

- the steam generation block is used in filtration experiments while simulating EOR using heat carriers and is a flow steam generator - over heater with thermocouples installed inside it for the heat carrier parameter monitoring. To control of steam parameters, a line with the back pressure valve maintaining the constant system pressure, and the capillary steel tube providing for pressure drops at the exit from the steam generator, due to which a degree of steam dryness can be controlled;

- the hydraulic line cooling block, as a rule, is used together with the steam generation block to cool fluid at the exit from the reservoir model and to maintain necessary temperature in the heat carrier pressure maintenance line in the steam generation block, and there is a cryostat, providing for circulation of a cooling agent in tubes with installed tubes of the hydraulic line of the filtration installation; 
Main technical parameters

of the filtration installation

\begin{tabular}{|c|c|}
\hline Parameter & Value \\
\hline \multicolumn{2}{|l|}{ General } \\
\hline Maximal operating formation pressure, MPa & 60.0 \\
\hline Maximal operating pore pressure, MPa & 40.0 \\
\hline Maximal operating temperature, ${ }^{\circ} \mathrm{C}$ & 200 \\
\hline Rangeofvolumetricflowof fluids, $\mathrm{cm}^{3} / \mathrm{min}$ & $0.001-50$ \\
\hline \multicolumn{2}{|l|}{ Core holder block } \\
\hline Core holder type & Hassler \\
\hline Diameter, mm & 30,110 \\
\hline Maximal length of core column, $\mathrm{mm}$ & 600 \\
\hline \multicolumn{2}{|l|}{ Slimtube block } \\
\hline Tube length, $\mathrm{m}$ & $12,24,40$ \\
\hline Outer tube diameter, $\mathrm{mm}$ & $6,8,12$ \\
\hline Material & Stainless steel \\
\hline Packing & $\begin{array}{c}\text { Glass } \\
\text { microspheres }\end{array}$ \\
\hline Fraction, mesh & 100 \\
\hline Porosity, \% & 38 \\
\hline${\text { Gas permeability,um }{ }^{2}}$ & 33 \\
\hline \multicolumn{2}{|l|}{ Fluids volume measurement block } \\
\hline Fluid flow range, $\mathrm{cm}^{3} / \mathrm{min}$ & $0.1-200$ \\
\hline Gas flow range, $\mathrm{cm}^{3} / \mathrm{min}$ & $0.1-500$ \\
\hline Accuracy, \% & 1 \\
\hline \multicolumn{2}{|l|}{ Maximal volume, $\mathrm{cm}^{3}$} \\
\hline- oil & 400 \\
\hline - gas & Unlimited \\
\hline - water & Unlimited \\
\hline \multicolumn{2}{|l|}{ Steam generation block } \\
\hline Maximal operating pressure, MPa & 25 \\
\hline Maximaloperatingtemperature, ${ }^{\circ} \mathrm{C}$ & 360 \\
\hline
\end{tabular}

- the superficial tension measurement block is for the superficial tension measurements in reservoir conditions using the hanging drop method and consisting of a high pressure cell with an observation window, spot light and high speed camera. Depending on the task, a visual cell is filled by a necessary transparent phase (water or gas), then oil is fed through a needle for further measurements of the superficial tension. The block determines the minimal miscibility pressure (MMP) using the VIT method.

The block design of the installation configures epy hydraulic line for experiments on oil displacement on core reservoir models and slimtube models, and to use additional blocks if they are necessary (steam generation, superficial tension measurement, hromatographic complex, etc.).
For operations with liquefying gases $\left(\mathrm{CO}_{2} \mathrm{Or}\right.$ gas mixtures), sealing rings of contacting elements in the hydraulic line are made of materials resistant to gas decompression.

Main technical parameters of the filtration installation are shown in Table, Fig. 3 presents the hydraulic circuit diagram of the filtration installation.

\section{Description of Experiments}

Preparatory works. To prepare the core models of the reservoir, a collection of standardsized cylindrical samples was pre-formed. Then to determine filtration and capacitance properties, the samples were taken with a regular shape, without chippings, fractures and large cavities on end planes and side surface. Porosity was determined by the fluid saturation method, gas permeability was determined with gas filtration using the sample method. Connate water saturation was created with the semipermeable membrane method in the group capillarimeter.

Arrangements of composite core models were performed according to provisions of the industry standard [42], according to values of the open porosity factors and absolute gas permeability of separate cylindrical samples.

Composite core models were arranged on condition of equality of their lengthily weighted porosity and gas permeability values, lengths and volumes of pores to exclude the influence of variations of these parameters on results of the experiments.

The work [43] shows that the initial oil saturation may exert a significant influence on the oil displacement factor value and gas-oil ratio. The higher the oil viscosity, the stronger the influence of the initial oil saturation on these parameters.

With regard to the above, the arrangement of the core models of the reservoir was performed so that values of the connate water saturation (and the initial oil saturation, as $S_{\text {oin. }}=1-S_{\text {w in. }}$ ) of the models were equivalent.

Preparation of the dissolved gas models was performed using the partial pressures static method. The method is to set the gas mixture 


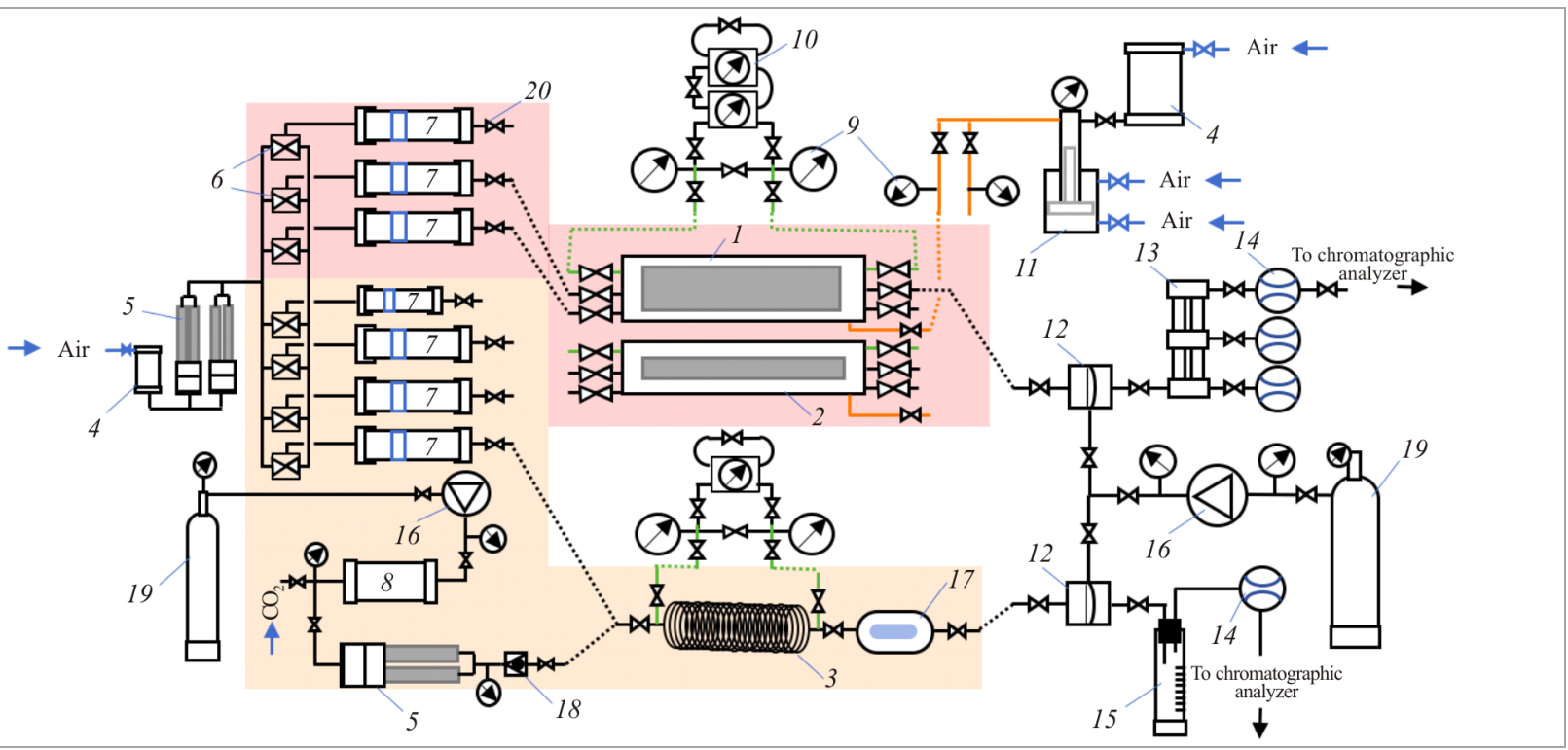

Fig. 3. Hydraulic circuit diagram of filtration installation: 1 - coreholder, $110 \mathrm{~mm} ; 2$ - coreholder, $30 \mathrm{~mm}$; 3 - slimmodel; 4 - oilvessel; 5 - plunger pumps; 6 - valves; 7 - high pressure vessel with moving piston; 8 - high pressure vessel; 9 - manometer; 10 - differential manometer; 11 - formation pressure piston pump; 12 - back pressure valve;13 - three-phase separator;14 - piston flowmeters; 15 - measurement burette;16 - pneumatic boosters; 17 - visual cell; 18 - back valve; 19 - gas cylinders; 20 - needle valve

composition (volumetric fractions of the components) according to partial pressures of separate components, on basis of equation (1):

$$
P_{\mathrm{mx}}=\sum_{i=1}^{n} P_{i},
$$

where $P_{\mathrm{mx}}$ is the gas mixture pressure, $P_{i}$ is the partial pressure of the gas component.

To determine the partial pressure of each gas, when setting the mixture using volumetric (molar) fractions, the Boyle-Mariotte law can be used, from which it comes that at constant temperature:

$$
P_{i}=P \frac{V_{i}}{V}=r_{i} P,
$$

where $V_{i}$ is the partial volume of the component; $V$ is the gas mixture volume; $r_{i}$ is the volumetric fraction of the mixture component.

So, setting a composition of a gas mixture is possible by adding partial pressures of the components:

$$
P_{\mathrm{mx}}=r_{i} P+r_{i+1} P+r_{n} P,
$$

where $r_{i}$ is the volumetric fraction of the gas component in the mixture.
For preparation of the recombined oil model and its mixtures with carbon dioxide, we used a pre-degassed and cleaned (from mechanical impurities) wellhead oil sample taken from wells of the Permian-Carboniferous reservior of the Usinskoye field.

For this purpose, the oil recombination cell was preliminarily pumped with the calculated amount of the reservoir gas model in the volume, corresponding to the necessary volume of the recombined oil model and average gas contents in oil at reservoir conditions.

During preparation of the recombined oil model with carbon dioxide, after the dissolved gas model, we pumped clean carbon dioxide. The volume of $\mathrm{CO}_{2}$ was calculated with regard to the 'dead volume' of tubes from the $\mathrm{CO}_{2}$ vessel up to the valve at the recombination vessel.

After pumping the gases into the recombination cell, the degassed oil was transferred using the high pressure vessel. Then pressure in the cell was raised up to the formation pressure, and temperature was set at the level above the formation temperature by $30-40{ }^{\circ} \mathrm{C}$.

Readiness of the recombined oil model was determined according to stabilization of gas 
contents, which was obtained by the single separation method during mixing.

The PVT properties of the recombined oil model were found according to [44]. At the stage of performing the PVT studies of the recombined oil model, a dependence of the volumetric ratio on pressure was additionally determined. This dependency was later used in calculations of the oil displacement factors at slim models and composite core models.

Determination of the oil displacement condition. The task of the filtration studies at slimmodels was to evaluate conditions of high-viscous oil displacements by carbon dioxide at different thermobaric conditions corresponding to those characteristic for areas of the Permian-Carboniferous reservior of the Usinskoye field.

Description of the experiment. The tube, preliminarily packed with quartzsand, was saturated with kerosene at pressure $7 \mathrm{MPa}$ to dissolve and eliminate air present in voids of the sand packing.

Kerosene was displaced by the recombinated oil model until stabilization of pressure differential at the experimental temperature and pressure, after which the slim model was hold at the fixed pressure and temperature for $24 \mathrm{~h}$.

Prepared $\mathrm{CO}_{2}$ (compressed and heated to the experimental conditions) was pumped to the slim model while maintaining the constant pressure differential at the level of $1.2 \mathrm{MPa}$.

Fluid volumes at the exit from the slim model were measured using the visual separator and special piston flowmeters.

Analysis of physical and chemical properties of the fluids being withdrawn was performed during the experiment.

$\mathrm{CO}_{2}$ was pumped in the volume corresponding to 1.2 volume of the slim model voids (at reservoir conditions), after which the experiment was stopped.

The oil displacement factor $\left(K_{\text {displ }}\right)$ was calculated according to equation (4):

$$
K_{\text {displ }}=\frac{V_{\text {vdo }} \cdot b-V_{\mathrm{dv}}}{V_{\text {por }}},
$$

where $V_{\text {vdo }}$ is the volume of the displaced oil, $\mathrm{cm}^{3}, b$ is the volumetric oil factor, corresponding to a degree of pore pressure and formation temperature, units, $V_{\mathrm{dv}}$ is the dead volume of tubes at the input to the slim model (determined by the geometric method), $\mathrm{cm}^{3}, V_{\text {por }}$ is the volume of pores of the slim model, equal to the volume of the oil initially present in the slim model, $\mathrm{cm}^{3}$.

After each experiment, the slim model was cleaned by pumping several pore volumes of the solvent until, its complete discoloration at the exit from the slim model at temperature $150{ }^{\circ} \mathrm{C}$.

The displacement condition was established according to the value of the oil displacement factor according to the established criteria: full miscibility is achieved on condition of displacement not less than $90 \%$ of oil, if the oil displacement factor is not more than 50-60\%, then the displacement process is of the nonmiscible character, obtaining the intermediary value of the displacement factor of 60-90 \% corresponds to the partial mixing conditions.

Filtration experiments on core reservoir models. According to the research objectives, experiments on the core models were performed at different isothermic conditions characterizing a warming degree of the reservoir of the Permian-Carboniferous reservior of the Usinskoye field.

Justification of the filtration speed. An important condition in simulating the filtration processes is reproduction of the actual filtration speed. In order to simulate reservoir conditions, it is necessary to have information on the actual filtration speed in the simulated object, but the existing filtration evaluation methods produce data on speed, as a rule, for the whole interval studied, where major inputs to the measurement is that of a highly permeable zone. That is why the data obtained are to significantly excessive and could not be used in filtration experiments for simulation of low permeable zones of the reservoir.

The character of displacement and phase movement in porous medium depends on a 
correlation of viscous, gravitational and capillary forces. Correlation between the viscous and capillary forces is described by nondimensional number $N_{c a}(5)$ :

$$
N_{c a}=\frac{V \mu D}{\sigma}
$$

where $v$ is the filtration speed; $\mu D$ is viscosity of the displacing phase (water or $\mathrm{CO}_{2}$ ); $\sigma$ is the superficial tension at the border of the phase being displaced and displacing phase.

A correlation between gravitational and capillary forces is characterized by the nondimensional Bond number $(B o)(6)$ :

$$
B o=\frac{\Delta \rho g K}{\sigma},
$$

where $\Delta \rho$ is the difference of densities in a phase being displaced and displacing phase; $g$ is a free fall acceleration; $K$ is permeability of the porous medium; $\sigma$ is the superficial tension at the border of a phase being displaced and displacing phase.

When simulating, the filtration capillary forces should prevail over other two forces, and, as it was said in [45], values of $N_{c a}$ and $B o$ should be less or equal to $10^{-5}$. During the experiments, parameters were selected on basis of this condition.

Experimental procedure. A preliminarily prepared core reservoir model was placed into the core holder and was saturated by kerosene. After this kerosene was displaced by the recombinated oil model. Oil filtration continued until reaching the stable pressure differential between end planes of the composite core model. After pressure stabilization, the differential phase permeability of oil $\left(K_{\mathrm{ppo}}\right)$ was determined at residual (connate) water saturation $\left(S_{\text {wst }}\right)$.

After thermal stabilization of the reservoir model and hydraulic system, the displacing agent (water or $\mathrm{CO}_{2}$ ) was pumped into the core reservoir model.

Measurement of the displaced volumes of fluids was performed with a certain periodicity in order to build the displacement dynamics graph, meanwhile the pressure differential was recorded for each time interval.

The displacement agent injection was performed until termination of the oil yield from reservoir model or after pumping of a volume equal to $2 V_{\text {por }}$ of the core reservoir model.

After the end of the experiment volume of oil extracted from the core oil model was calculated, accounting for the 'dead volume' of tubes at the exit from the core holder.

Basing on the known volume of the oil initially present in pores of the core reservoir model, the calculation of the oil displacement factor $\left(K_{\text {displ }}\right)$ was performed according to Equation (7):

$$
K_{\mathrm{displ}}=\frac{V_{\mathrm{vdo}} \cdot b-V_{\mathrm{dv}}}{V_{\mathrm{por}}-V_{\mathrm{vcw}}},
$$

where $V_{\text {por }}$ is the volume of pores in reservoir model, $\mathrm{cm} ; V_{\text {св в }}$ is the volume of connate water in the reservoir model, $\mathrm{cm}$.

\section{Conclusions}

1. Advanced laboratory facilities are developed, which perform the whole range of researches necessary to study the thermal and gas EOR.

2. A methodology is proposed for an integrated evaluation of effectiveness of the HVO recovery technology, using the experimental and numerical methods.

3. Procedures are developed to research the combined technology for injecting heat carriers and carbon dioxide in order to increase the oil recovery factor at the Permian-Carboniferous reservior of the the Usinskoye field.

\section{References}

1. Ruzin L.M., Chuprov I.F., Moroziuk O.A., Durkin S.M. Tekhnologicheskie printsipy razrabotki zalezhei anomal'no viazkikh neftei i bitumov [Technological principles for the development of deposits of abnormally viscous oils and bitumen]. 2nd ed. Moscow. Izhevsk: Institut komp'iuternykh issledovanii, 2015, 480 p. 
2. Chemical, physical and thermal properties of carbon dioxide. Phase diagram included, available at: https://www.engineeringtoolbox. com/ $\mathrm{CO}_{2}$-carbon-dioxide-properties-d_2017.html (accessed 17 November 2018).

3. Anwar S., Carroll J.J. Carbon Dioxide Thermodynamic Properties Handbook: Covering Temperatures from $-20^{\circ}$ to $250^{\circ} \mathrm{C}$ and Pressures up to 1000 Bar, Second Edition. Scrivener Publishing LLC. Published by John Wiley \& Sons, Inc., 2016, 578 p.

4. Kalinin S.A., Moroziuk O.A. Razrabotka mestorozhdenii vysokoviazkoi nefti $\mathrm{v}$ karbonatnykh kollektorakh $\mathrm{s}$ ispol'zovaniem dioksida ugleroda. Analiz mirovogo opyta [Using carbon dioxide to develop highly viscous oil fields in carbonate reservoirs. Global experience analysis]. Vestnik Permskogo natsional'nogo issledovatel'skogo politekhnicheskogo universiteta. Geologiia. Neftegazovoe i gornoe delo, 2019, vol. 19, no. 4, pp. 373-387. DOI: 10.15593/2224-9923/2019.4.6

5. Si Ch., Tsi Ts., Liu T., Chzhan Iu., Chzhao F., Iui Ts., Shen' D., Li S. Tekhnologiia vytesneniia nefti parom $\mathrm{s}$ dobavkoi uglekislogo gaza $\mathrm{SO}_{2}$ na pozdnei stadii vytesneniia nefti parom - na primere bloka J6 mestorozhdeniia Sin'tszian $\left[\mathrm{CO}_{2}\right.$ Assisted Steam Flooding Technology after Steam Flooding - A Case Study in Block J6 of Xinjiang Oilfield ]. Rossiiskaia neftegazovaia tekhnicheskaia konferentsiia SPE. 22-24 October, Moscow, 2019. DOI: $10.2118 / 196767-R U$

6. Chzhan Iu., Dekhuan Shen', Iunzhun Gao et al. Fizicheskoe modelirovanie tekhnologii zakachki $\mathrm{CO}_{2} \quad \mathrm{v}$ protsesse parogravitatsionnogo drenazha [Physical simulation experiments on $\mathrm{CO}_{2}$ injection technology during steam assisted gravity drainage process]. Acta Petrolei Sinica, 2014, vol. 35, no. 6, pp. 1147-1152. DOI: $10.7623 /$ syxb201406012

7. Liu Sh., Sh., Gao Iu. et al. Issledovanie tekhnologii parovogo zatopleniia s dobavkoi $\mathrm{CO}_{2}$ $\mathrm{v}$ vertikal'nykh i gorizontal'nykh skvazhinakh [Study on $\mathrm{CO}_{2}$-assisted steam flooding process combined vertical and horizontal wells].
Acta Petrolei Sinica, 2008, vol. 29, no. 3, pp. 414-417. DOI: $10.7623 /$ syxb200803019

8. Wang C., Liu P., Wang F. et al. Experimental study on effects of $\mathrm{CO}_{2}$ and improving oil recovery for $\mathrm{CO}_{2}$ assisted SAGD in super-heavy-oil reservoirs. Journal of Petroleum Science and Engineering, 2018, 165, pp. 1073-1080. DOI: 10.1016/j.petrol.2018.02.058

9. Lake L.W. Enhanced Oil Recovery Fundamentals. Society of Petroleum Engineers, 2014, 496 pp.

10. Babalian G.A. Primenenie karbonizirovannoi vody dlia uvelicheniia nefteotdachi [Application of carbonated water to enhance oil recovery]. Moscow: Nedra, 1976, $144 \mathrm{p}$.

11. Glazova V.M., Ryzhik V.M. Primenenie dvuokisi ugleroda dlia povysheniia nefteotdachi plastov za rubezhom [The use of carbon dioxide for enhanced oil recovery abroad]. Moscow: VNIIOENG, 1986, 45 p.

12. Zhang N., Wei M., Bai B. Statistical and analytical review of worldwide $\mathrm{CO}_{2}$ immiscible field applications. Fuel, 2018, vol. 220, pp. 89-100. DOI: $10.1016 /$ j.fuel.2018.01.140

13. Luo P., Erl V., Freitag N., Huang S. Recharacterizing evolving fluid and PVT properties of Weyburn oil- $\mathrm{CO}_{2}$ system. International Journal of Greenhouse Gas Control, 2013, no. 16, pp. 226-235. DOI: 10.1016/j.ijggc.2013.03.001

14. Miller J.S., Jones A.J. A laboratory study to determine physical characteristics of heavy oil after $\mathrm{CO}_{2}$ saturation. Second Joint Symposium on Enhanced Oil Recovery of the Society of Petroleum Engineers held in Tulsa, Oklahoma, ApriI 8, 1981. DOI: $10.2118 / 9789-\mathrm{MS}$

15. F.M. Orr Jr., Yu A.D., Lien, C.L. Phase Behavior of $\mathrm{CO}_{2}$ and Crude Oil in LowTemperature Reservoirs. SPE Journal, 1981, vol. 21, no. 4, pp. 480-492. DOI: $10.2118 / 8813-P A$

16. Chung F.T.H., Ray A.J., Hal T.N. Measurements and Correlations of the Physical Properties of $\mathrm{CO}_{2} /$ HeavyCrude-Oil Mixtures. SPE Journal, 1988, 
vol. 3, no. 3, pp. 822-828. DOI: $10.2118 / 15080-P A$

17. Lobanov A.A., Zvonkov M.A., Khlan' M.V., Pustova E.Iu., Kovalenko V.A., Zolotukhin A.B. Osobennosti vzaimodeistviia szhizhennogo uglekislogo gaza s vysokoviazkoi neft'iu. Chast' 1. Ob"emnoe i fazovoe povedenie smesei [Peculiarities of interaction of liquefied carbon-dioxide gas with highviscous oil. Part I. Mixtures volume and phase behavior]. Neftepromyslovoe delo, 2018, no. 4, pp. 24-30. DOI: 10.30713/02072351-2018-4-24-30

18. Lobanov A.A. Shchekoldin K.A., Zvonkov M.A., Khlan' M.V., Pustova E.Iu., Kovalenko V.A., Struchkov I.A., Zolotukhin A.B. Osobennosti vzaimodeistviia szhizhennogo uglekislogo gaza s vysokoviazkoi neft'iu. Chast' 2. Svoistva faz [Peculiarities of interaction of liquefied carbon gas with high viscous oil. Part 2. Properties of phases]. Neftepromyslovoe delo, 2018, no. 5, pp. 47-53. DOI: 10.30713/0207-2351-2018-5-47-53

19. Lashkarbolooki M., Riazi M., Ayatollahi S. Experimental investigation of dynamic swelling and Bond number of crude oil during carbonated water flooding; Effect of temperature and pressure. Fuel, 2018, no. 214, pp. 135-143. DOI: 10.1016/j.fuel.2017.11.003

20. Zhang W., Wang Y., Ren T. Influence of injection pressure and injection volume of $\mathrm{CO}_{2}$ on asphaltene deposition. Petroleum Science and Technology, 2017, vol. 35, no. 4, pp. 313-318. DOI: $10.1080 / 10916466.2016 .1258419$

21. Sharma A.K., Patil S.L., Kamath V.A., Sharma G.D. Miscible Displacement of Heavy West Sak Crude by Solvents in Slim Tube. SPE California Regional Meeting held in Bakersfield. California, April 5-7, 1989. DOI: 10.2118/18761-MS

22. Elsharkawy A.M., Poettmann F.H., Christiansen R.L. Measuring Minimum Miscibility Pressure: Slim-Tube or Rising-Bubble Method? Eighth Symposium on Enhanced Oil Recovery held in Tulsa. Oklahoma, April 22-24, 1992. DOI: $10.2118 / 24114-\mathrm{MS}$
23. Lian Men. Fizicheskoe modelirovanie vytesneniia nefti gazom (rastvoritelem) $\mathrm{s}$ ispol'zovaniem kernovykh modelei plasta $\mathrm{i}$ slim-tube [Physical modeling of oil displacement by gas (solvent) using reservoir core models and slim-tube]. Ph. D. thesis. Moscow, 2016, pp. 85-86.

24. $\mathrm{Wu}$ R.S., Batycky J.P. Evaluation of miscibility from slim tube tests. The Journal of Canadian Petroleum Technology, 1990, vol. 29, no. 6, pp. 63-70. DOI: $10.2118 / 90-06-06$

25. Christiansen R.L., Haines H.K. Rapid Measurement of Minimum Miscibility Pressure with the Rising- Bubble Apparatus. SPE Res. Eng, 1987, vol. 2, no. 4, pp. 523-527. DOI: 10.2118/13114-PA

26. Rao D.N., Lee J.I. Evaluation of Minimum Miscibility Pressure and Composition for Terra Nova Offshore Project Using the New Vanishing Interfacial Tension Technique. SPE/DOE Improved Oil Recovery Symposium, 2000. DOI: $10.2118 / 59338-\mathrm{ms}$

27. Radaev A.V., Batrakov N.R., Kondrat'ev I.A., Mukhamadiev A.A., Sabirzianov A.N. Eksperimental'noe issledovanie protsessa vytesneniia vysokoviazkoi nefti sverkhkriticheskim dioksidom ugleroda $\mathrm{v}$ shirokom diapazone termobaricheskikh uslovii [Experimental research of process of replacement heavy oil by supercritical carbon dioxide in the wide range of thermobaric conditions]. Georesursy, 2010, no. 2 (34), pp. 16-18, available at: https://cyberleninka.ru/article/n/eksperimentalnoeissledovanie-protsessa-vytesneniya-vysokovyazkoynefti-sverhkriticheskim-dioksidom-ugleroda-v-shirokom-diapazone (accessed 10 February 2020).

28. Radaev A.V., Nasyrov E.R., Batrakov N.R., Mukhamadiev A.A., Sabirzianov A.N. Vliianie termobaricheskikh uslovii na koeffitsient vytesneniia neftei razlichnoi viazkosti sverkhkriticheskim dioksidom ugleroda [Influence of thermobaric conditions on the coefficient of displacement of oils of different viscosity by supercritical carbon dioxide]. Vesti gazovoi nauki, 2011, no. 2 (7), available at: https://cyberleninka.ru/article/n/vliyanie-termobaricheskih-usloviy-na-koeffitsient-vytesneniya-neftey- 
razlichnoy-vyazkosti-sverhkriticheskim-dioksidom$\begin{array}{llll}\text { ugleroda } & \text { (accessed } & 07 & \text { February }\end{array}$ 2020).

29. Filenko D.G., Dadashev M.N., Vinokurov V.A., Grigor'ev B.A. Issledovanie vliianiia termobaricheskikh uslovii na vytesnenie nefti dioksidom ugleroda $\mathrm{v}$ sverkhkriticheskom sostoianii [Study of the influence of thermobaric conditions on the displacement of oil by carbon dioxide in the supercritical state]. Vesti gazovoi nauki, 2012, no. 3 (11), available at: https:// cyberleninka.ru/article/n/issledovanie-vliyaniya-termobaricheskih-usloviy-na-vytesnenie-nefti-dioksidomugleroda-v-sverhkriticheskom-sostoyanii (accessed 25 January 2020).

30. Wolcott J., Schenewerk P., Berzins T., Karim F. A parametric investigation of the cyclic $\mathrm{CO}_{2}$ injection process. Journal of Petroleum Science and Engineering, 1995, no. 14, pp. 35-44. DOI: 10.1016/0920-4105(95)00020-8

31. Zheng S., Li H., Yang D. Pressure maintenance and improving oil recovery with immiscible $\mathrm{CO}_{2}$ injection in thin heavy oil reservoirs. Journal of Petroleum Science and Engineering, 2013, vol. 112, pp. 139-152. DOI: $10.1016 /$ j.petrol.2013.10.020

32. Seyyedsar S.M., Farzaneh S.A., Sohrabi M. Experimental investigation of tertiary $\mathrm{CO}_{2}$ injection for enhanced heavy oil recovery. Journal of Natural Gas Science and Engineering, 2016, vol. 34, pp. 1205-1214. DOI: $10.1016 /$ j.jngse.2016.08.020

33. Wang Z., Ma J., Gao R., Zeng F., Huang C., Tontiwachwuthikul P., Liang Z. Optimizing Cyclic $\mathrm{CO}_{2}$ Injection for Low-permeability Oil Reservoirs through Experimental Study. Unconventional Resources Conference-Canada held in Calgary. Alberta, Canada, 5-7 November, 2013. DOI: $10.2118 / 167193-M S$

34. Iraji B., Shadizadeh S.R., Riazi M. Experimental investigation of $\mathrm{CO}_{2}$ huff and puff in a matrix-fracture system. Fuel, 2015, vol. 158, no. 15, pp. 105-112. DOI: 10.1016/j.fuel.2015.04.069

35. Alireza Emadi Enhanced heavy oil recovery by water and carbon dioxide flood: Submitted for the Degree of Doctoral of Philosophy in Petroleum Engineering. Edinburgh, 2012.

36. Liu S.C., Sharma M.P., Harris H.G. Steam And $\mathrm{CO}_{2}$ Combination Flooding of Fractured Cores: Experimental Studies. 46th Annual Technical Meeting of The Petroleum Society of CIM in Banff. Alberta, Canada, May 14-17, 1995. DOI: $10.2118 / 95-80$

37. Bagci A.S., Gumrah F. Effects of $\mathrm{CO}_{2}$ and $\mathrm{CH}_{4}$ addition to steam on recovery of West Kozluca heavy oil. SPE International Thermal Operations and Heavy Oil Symposium and Western Regional Meeting, 16-18 March. Bakersfield, California, 2004. DOI: $10.2118 / 86953-\mathrm{MS}$

38. Emadi A., Sohrabi M., Farzaneh S.A., Ireland $\mathrm{S}$. Experimental investigation of Liquid- $\mathrm{CO}_{2}$ and $\mathrm{CO}_{2}$-Emulsion Application for enhanced heavy oil recovery. SPE EAGE Annual Conference \& Exhibition incorporating SPE Europec, 10-13 June. London, UK, 2013. DOI: $10.3997 / 2214-$ 4609.20130508

39. Zhang Y.P., Luo P., Huang S. Improved heavy oil recovery by $\mathrm{CO}_{2}$ injection augmented with chemicals. SPE International Oil and Gas Conference and Exhibition in China, 8-10 June. Beijing, China, 2010. DOI: $10.2118 / 131368-M S$

40. Torabi F., Qazvini Firouz A., Kavousi A., Asghari K. Comparative evaluation of immiscible, near miscible and miscible $\mathrm{CO}_{2}$ huff-n-puff to enhance oil recovery from a single matrix-fracture system (experimental and simulation studies). Fuel, 2012, vol. 93, pp. 443-453. DOI: 10.1016/j.fuel.2011.08.037

41. Moradi B., Awang M., Sabil K.M., Shoushtari M.A., Moradi P., Ajdari Hamzeh, Shuker M.T. Liquid carbon dioxide flooding in low temperature oil reservoirs. SPE Asia Pacific Oil and Gas Conference and Exhibition, 22-24 October. Jakarta, Indonesia, 2013. DOI: $10.2118 / 165888-M S$

42. OST 39-195-86. Neft'. Metod opredeleniia koeffitsienta vytesneniia nefti vodoi $\mathrm{v}$ laboratornykh usloviiakh 
[OST 39-195-86. Oil. Method for determining the coefficient of oil displacement by water in laboratory conditions]. Moscow, 1986.

43. Klins M.A., Ali S.M.F. Heavy Oil Production By Carbon Dioxide Injection. Journal of Canadian Petroleum Technology, 1982, vol. 21 (05). DOI: $10.2118 / 82-05-06$

44. OST 153-39.2-048-2003. Neft'. Tipovye issledovaniia plastovykh fliuidov i separirovannykh neftei [OST 153-39.2048-2003. Oil. Routine studies of reservoir fluids and separated oils]. Moscow, 2003.

45. Green D.W., Willhite G.P. Enhanced Oil Recovery. Society of Petroleum Engineers, 1986. 545 pp.

\section{Библиографический список}

1. Технологические принципы разработки залежей аномально вязких нефтей и битумов / Л.М. Рузин, И.Ф. Чупров, О.А. Морозюк, С.М. Дуркин. - 2-е изд., перераб. и доп. М.; Ижевск: Институт компьютерных исследований, 2015. - 480 с.

2. Chemical, physical and thermal properties of carbon dioxide. Phase diagram included. [Электронный ресурc]. - URL: https://www.engineeringtoolbox.com/CO2-carbon-dioxide-properties-d_2017.html (дата обращения: 17.11.2018).

3. Anwar S., Carroll J.J. Carbon Dioxide Thermodynamic Properties Handbook: Covering Temperatures from $-20^{\circ}$ to $250^{\circ} \mathrm{C}$ and Pressures up to 1000 Bar, Second Edition. Scrivener Publishing LLC. - Published by John Wiley \& Sons, Inc., 2016. - 578 p.

4. Калинин С.А., Морозюк О.А. Разработка месторождений высоковязкой нефти в карбонатных коллекторах с использованием диоксида углерода. Анализ мирового опыта // Вестник Пермского национального исследовательского политехнического университета. Геология. Нефтегазовое и горное дело. 2019. - T. 19, № 4. - C. 373-387. DOI: 10.15593/2224-9923/2019.4.6
5. Технология вытеснения нефти паром с добавкой углекислого газа $\mathrm{CO}_{2}$ на поздней стадии вытеснения нефти паром - на примере блока J6 месторождения Синьцзян / Ч. Си, Ц. Ци, Т. Лю, Ю. Чжан, Ф. Чжао, Ц. Юй, Д. Шэнь, С. Ли // Российская нефтегазовая техническая конференция SPE. - M., 22-24 октября, 2019. DOI: $10.2118 / 196767-R U$

6. Физическое моделирование технологии закачки $\mathrm{CO}_{2}$ в процессе парогравитационного дренажа / Ю. Чжан, Шэнь Дэхуан, Гао Юнжун [и др.] // Acta Petrolei Sinica. - 2014. - Vol. 35, № 6. P. 1147-1152. DOI: 10.7623/syxb201406012

7. Исследование технологии парового затопления с добавкой $\mathrm{CO}_{2}$ в вертикальных и горизонтальных скважинах / Ш. Лю, Ш. Ян, Ю. Гао [и др.] // Acta Petrolei Sinica. - 2008. - Vol. 29, № 3. - P. 414-417. DOI: $10.7623 /$ syxb200803019

8. Experimental study on effects of $\mathrm{CO}_{2}$ and improving oil recovery for $\mathrm{CO}_{2}$ assisted SAGD in super-heavyoil reservoirs / C. Wang, P. Liu, F. Wang [et al.] // Journal of Petroleum Science and Engineering. - 2018. - 165. - P. 1073-1080. DOI: $10.1016 /$ j.petrol.2018.02.058

9. Lake L.W. Enhanced Oil Recovery Fundamentals. - Society of Petroleum Engineers, 1985. - 2014. - 496 p.

10. Бабалян Г.А. Применение карбонизированной воды для увеличения нефтеотдачи М.: Недра, 1976 - 144 с.

11. Глазова В.М., Рыжик В.М. Применение двуокиси углерода для повышения нефтеотдачи пластов за рубежом. - М.: Изд-во ВНИИОЭНГ, 1986. - 45 с.

12. Zhang N., Wei M., Bai B. Statistical and analytical review of worldwide $\mathrm{CO}_{2}$ immiscible field applications // Fuel. 2018. - Vol. 220. - P. 89-100. DOI: 10.1016/j.fuel.2018.01.140

13. Recharacterizing evolving fluid and PVT properties of Weyburn oil- $\mathrm{CO}_{2}$ system / P. Luo, V. Erl, N. Freitag, S. Huang // International Journal of Greenhouse Gas Control. - 2013. - № 16. - P. 226-235. DOI: 10.1016/j.ijggc.2013.03.001 
14. Miller J.S., Jones A.J. A laboratory study to determine physical characteristics of heavy oil after $\mathrm{CO}_{2}$ saturation // Second Joint Symposium on Enhanced Oil Recovery of the Society of Petroleum Engineers held in Tulsa. - Oklahoma, ApriI·8, 1981. DOI: $10.2118 / 9789-\mathrm{MS}$

15. F.M. Orr Jr., Yu A.D., Lien C.L. Phase Behavior of $\mathrm{CO}_{2}$ and Crude Oil in Low-Temperature Reservoirs // SPE Journal. - 1981. - Vol. 21, № 4. - P. 480-492. DOI: $10.2118 / 8813-\mathrm{PA}$

16. Chung F.T.H., Ray A.J., Hal T.N. Measurements and Correlations of the Physical Properties of $\mathrm{CO}_{2} /$ HeavyCrude-Oil Mixtures // SPE Journal. 1988. - Vol. 3, № 3. P. 822-828. DOI: $10.2118 / 15080-P A$

17. Особенности взаимодействия сжиженного углекислого газа с высоковязкой нефтью. Часть 1. Объемное и фазовое поведение смесей / А.А. Лобанов, М.А. Звонков, М.В. Хлань, Е.Ю. Пустова, В.А. Коваленко, А.Б. Золотухин // Нефтепромысловое дело. - 2018. № 4. - C. 24-30. DOI: 10.30713/0207-23512018-4-24-30

18. Особенности

сжиженного углекислого газа с высоковязкой нефтью. Часть 2. Свойства фаз / А.А. Лобанов, К.А. Щеколдин, М.А. Звонков, М.В. Хлань, Е.Ю. Пустова, В.А. Коваленко, И.А. Стручков, А.Б. Золотухин // Нефтепромысловое дело. 2018. - № 5. - C. 47-53. DOI: 10.30713/02072351-2018-5-47-53

19. Lashkarbolooki M., Riazi M., Ayatollahi S. Experimental investigation of dynamic swelling and Bond number of crude oil during carbonated water flooding; Effect of temperature and pressure // Fuel. 2018. - № 214. - P. 135-143. DOI: $10.1016 /$ j.fuel.2017.11.003

20. Zhang W., Wang Y., Ren T. Influence of injection pressure and injection volume of $\mathrm{CO}_{2}$ on asphaltene deposition // Petroleum Science and Technology. 2017. - Vol. 35, № 4. - P. 313-318. DOI: $10.1080 / 10916466.2016 .1258419$
21. Miscible Displacement of Heavy West Sak Crude by Solvents in Slim Tube / A.K. Sharma, S.L. Patil, V.A. Kamath, G.D. Sharma // SPE California Regional Meeting held in Bakersfield. - California, April 5-7, 1989. DOI: 10.2118/18761-MS

22. Elsharkawy A.M., Poettmann F.H., Christiansen R.L. Measuring Minimum Miscibility Pressure: Slim-Tube or Rising -Bubble Method? // Eighth Symposium on Enhanced Oil Recovery held in Tulsa. - Oklahoma, April 22-24, 1992. DOI: $10.2118 / 24114-\mathrm{MS}$

23. Лян Мэн Физическое моделирование вытеснения нефти газом (растворителем) с использованием керновых моделей пласта и slim-tube: дис. ... канд. техн. наук (25.00.2017). M., 2016. - C. 85-86.

24. Wu R.S., Batycky J.P. Evaluation of miscibility from slim tube tests // The Journal of Canadian Petroleum Technology. - 1990. - Vol. 29, № 6. - P. 63-70. DOI: 10.2118/90-06-06

25. Christiansen R.L., Haines H.K. Rapid Measurement of Minimum Miscibility Pressure with the Rising- Bubble Apparatus // SPE Res. Eng. - 1987. - Vol. 2, № 4. - P. 523-527. DOI: 10.2118/13114-PA

26. Rao D.N., Lee J.I. Evaluation of Minimum Miscibility Pressure and Composition for Terra Nova Offshore Project Using the New Vanishing Interfacial Tension Technique // SPE/DOE Improved Oil Recovery Symposium. - 2000. DOI:10.2118/59338-ms

27. Экспериментальное исследование процесса вытеснения высоковязкой нефти сверхкритическим диоксидом углерода в широком диапазоне термобарических условий [Электронный ресурс] / А.В. Радаев, Н.Р. Батраков, И.А. Кондратьев, А.А. Мухамадиев, А.Н. Сабирзянов // Георесурсы. - 2010. № 2 (34). - C. 16-18. - URL: https://cyberleninka.ru/article/n/eksperimentalnoe-issledovanie-protsessa-vytesneniya-vysokovyazkoy-nefti-sverhkriticheskim-dioksidom-ugleroda-v-shirokom-diapazone (дата обращения: 10.02.2020).

28. Влияние термобарических условий на коэффициент вытеснения нефтей различной 
вязкости сверхкритическим диоксидом углерода [Электронный ресурс] / А.В. Радаев, Э.Р. Насыров, Н.Р. Батраков, А.А. Мухамадиев, А.Н. Сабирзянов // Вести газовой науки. 2011. - № 2 (7). - URL: https://cyberleninka.ru/ article/n/vliyanie-termobaricheskih-usloviy-na-koeffitsient-vytesneniya-neftey-razlichnoy-vyazkosti-sverhkriticheskim-dioksidom-ugleroda (дата обращения: 07.02.2020).

29. Исследование влияния термобарических условий на вытеснение нефти диоксидом углерода в сверхкритическом состоянии [Электронный ресурс] / Д.Г. Филенко, М.Н. Дадашев, В.А. Винокуров, Б.А. Григорьев // Вести газовой науки. - 2012. - № 3 (11). URL: https://cyberleninka.ru/article/n/issledovanievliyaniya-termobaricheskih-usloviy-na-vytesnenienefti-dioksidom-ugleroda-v-sverhkriticheskom-sostoyanii (дата обращения: 25.01.2020).

30. A parametric investigation of the cyclic $\mathrm{CO}_{2}$ injection process / J. Wolcott, P. Schenewerk, T. Berzins, F. Karim // Journal of Petroleum Science and Engineering. - 1995. - № 14. P. 35-44. DOI: 10.1016/0920-4105(95)00020-8

31. Zheng S., Li H., Yang D. Pressure maintenance and improving oil recovery with immiscible $\mathrm{CO}_{2}$ injection in thin heavy oil reservoirs // Journal of Petroleum Science and Engineering. - 2013. - Vol. 112. - P. 139-152. DOI: $10.1016 /$ j.petrol.2013.10.020

32. Seyyedsar S. M., Farzaneh S.A., Sohrabi M. Experimental investigation of tertiary $\mathrm{CO}_{2}$ injection for enhanced heavy oil recovery // Journal of Natural Gas Science and Engineering. - 2016. - Vol. 34. - P. 1205-1214. DOI: $10.1016 /$ j.jngse.2016.08.020

33. Optimizing Cyclic $\mathrm{CO}_{2}$ Injection for Low-permeability Oil Reservoirs through Experimental Study / Z. Wang, J. Ma, R. Gao, F. Zeng, C. Huang, P. Tontiwachwuthikul, Z. Liang // Unconventional Resources Conference-Canada held in Calgary. Alberta, Canada, 5-7 November, 2013. DOI: $10.2118 / 167193-M S$

34. Iraji B., Shadizadeh S.R., Riazi M. Experimental investigation of $\mathrm{CO}_{2}$ huff and puff in a matrix-fracture system // Fuel. 2015. - Vol. 158, № 15. - P. 105-112. DOI: 10.1016/j.fuel.2015.04.069
35. Alireza Emadi Enhanced heavy oil recovery by water and carbon dioxide flood: Submitted for the Degree of Doctoral of Philosophy In Petroleum Engineering. Edinburgh, 2012.

36. Liu S.C., Sharma M.P., Harris H.G. Steam And $\mathrm{CO}_{2}$ Combination Flooding of Fractured Cores: Experimental Studies // 46th Annual Technical Meeting of The Petroleum Society of CIM in Banff. Alberta, Canada, May 14-17, 1995. DOI: $10.2118 / 95-80$

37. Bagci A.S., Gumrah F. Effects of $\mathrm{CO}_{2}$ and $\mathrm{CH}_{4}$ addition to steam on recovery of West Kozluca heavy oil // SPE International Thermal Operations and Heavy Oil Symposium and Western Regional Meeting, 16-18 March. - Bakersfield, California, 2004. DOI: $10.2118 / 86953-\mathrm{MS}$

38. Experimental investigation of Liquid- $\mathrm{CO}_{2}$ and $\mathrm{CO}_{2}$-Emulsion Application for enhanced heavy oil recovery / A. Emadi, M. Sohrabi, S.A. Farzaneh, S. Ireland // SPE EAGE Annual Conference \& Exhibition incorporating SPE Europec, 10-13 June. London, UK, 2013. DOI: $10.3997 / 2214-$ 4609.20130508

39. Zhang Y.P., Luo P., Huang S. Improved heavy oil recovery by $\mathrm{CO}_{2}$ injection augmented with chemicals // SPE International Oil and Gas Conference and Exhibition in China, 8-10 June. - Beijing, China, 2010. DOI: $10.2118 / 131368-M S$

40. Comparative evaluation of immiscible, near miscible and miscible $\mathrm{CO}_{2}$ huff-n-puff to enhance oil recovery from a single matrix-fracture system (experimental and simulation studies) / F. Torabi, A. Qazvini Firouz, A. Kavousi, K. Asghari // Fuel. 2012. - Vol. 93. - P. 443-453. DOI: $10.1016 /$ j.fuel.2011.08.037

41. Liquid carbon dioxide flooding in low temperature oil reservoirs / B. Moradi, M. Awang, K.M. Sabil, M.A. Shoushtari, P. Moradi, Hamzeh Ajdari, M.T. Shuker // SPE Asia Pacific Oil and Gas Conference and Exhibition, 22-24 October. - Jakarta, Indonesia, 2013. DOI: $10.2118 / 165888-M S$ 
42. ОСТ 39-195-86. Нефть. Метод определения коэффициента вытеснения нефти водой в лабораторных условиях. - М., 1986.

43. Klins M.A., Ali S.M.F. Heavy Oil Production By Carbon Dioxide Injection // Journal of Canadian Petroleum Technology. 1982. - Vol. 21 (05). DOI:10.2118/82-05-06
44. ОСТ 153-39.2-048-2003. Нефть. Типовые исследования пластовых флюидов и сепарированных нефтей. - M., 2003.

45. Green D.W., Willhite G.P. Enhanced Oil Recovery // Society of Petroleum Engineers. 1986. - 545 p.

Please cite this article in English as:

Kalinin S.A., Morozyuk O.A. Laboratory Studies of Carbonate Reservoirs in High-Viscosity Oil Fields using Carbon Dioxide. Perm Journal of Petroleum and Mining Engineering, 2020, vol.20, no.4, pp.369-385. DOI: $10.15593 / 2712-8008 / 2020.4 .6$

Просьба ссылаться на эту статью в русскоязычных источниках следующим образом:

Калинин С.А., Морозюк О.А. Лабораторные исследования карбонатных коллекторов месторождений высоковязкой нефти с использованием диоксида углерода // Недропользование. - 2020. - Т.20, №4. - С.369-385. DOI: $10.15593 / 2712-8008 / 2020.4 .6$ 